\title{
Editorlal
}

\section{The drafting of European Community directives}

\author{
J. David B. Oliver, Coopers \& Lybrand Deloitte, London
}

Drafting tax legislation is never an easy matter and when the drafting has to try and embrace different national systems and differences of approach it is therefore even more difficult. One wonders, however, whether, in relation to the July 1990 directives and the November 1990 proposal, sufficient expertise is going into the initial drafting of these directives. Are they being prepared by members of the treasuries or finance organisations? How much imput is received from the different national tax authorities? Perhaps it needs the broader approach of the finance ministry or treasury to drive forward a directive but there are some indications that perhaps not as much technical input is received at as earlier a stage as might be desirable.

Two examples of this can be given. The first concerns the dividends directive. It was only at a very late stage that qualification under the directive (Article II) was amended to deal with the position of a dual resident company. Article II (b) now states that a company of a member state means any company which 'according to the tax laws of a member state is considered to be resident in that state for tax purposes and, under the terms of a double taxation agreement concluded with a third state, is not considered to be resident for tax purposes outside the community', this recognised that a dual resident company might otherwise qualify for the benefit of the directive. Such a dual resident would be incorporated in a member state so that it would take one of the forms listed in the annexe and would be considered to be resident in that state for tax purposes but would locate its centre of effective management in some third country outside the Community. Thus, under an appropriate double tax treaty between the member state and that third country, the company would claim treaty protection from taxation by the member state.

Another example is the proposal for 'a council directive concerning arrangements for the taking into account by enterprises of the losses of their permanent establishments and subsidiaries situated in other member states'. Although this has only been published as a proposal it is a little surprising that it does not pay more attention to the arrangements for relieving losses which may already be in force in different member states. It envisages that a parent company in state A can claim to set off against its profits the losses of a directly owned subsidiary in state B. On the other hand the losses of that subsidiary may themselves be set off against profits of other subsidiaries in state B. Therefore, relief for the losses would be obtained twice, once in state A and again in state B. While this would be very welcome to the tax payer companies, or perhaps one should say the non tax paying companies, this can hardly be what was intended. Of course the explanatory memorandum accompanying the proposal makes it clear that there are many issues (of which this must certainly be one) which are open for discussion. However, it does seem a little surprising that the point has not been picked up already.

Another aspect of the directives, and proposed directives, is the tendency to look only at directly owned companies so they do not extend to other companies within the same group including some subsidiaries or fellow subsidiaries. This is understandable in the case of double tax treaties where problems are being tackled on a bi-lateral basis and it is relevant only to look at enterprises in the state B which are directly owned by enterprises in state A. On the other hand the directives are seeking to apply a multi-lateral solution and are only hampering this by using a technique of bi-lateral solutions. They proceed on a basis which assumes the existence of a 'tooth-comb structure' where all subsidiaries are directly owned by the parent and do not cater for the more usual 'Christmas tree structure'. No doubt the imaginative planner can help devise ways in which transactions between companies in a Christmas tree structure can be arranged to have the same effect as if there was a tooth-comb structure but why should people be forced to go to these lengths? Perhaps the difficulty of proving intermediate ownership is the problem. 